\title{
Plato as Prophet
}

\author{
Robert J. Taormina \\ University of Macau, Macau (SAR), CHINA
}

Received 25 May 2019 • Revised 21 September 2019 • Accepted 30 September 2019

\begin{abstract}
This article endeavors to ascertain whether Plato may be regarded as a prophet. This involves defining what a prophet is and examining a number of literary sources in order to uncover the needed evidence and to make appropriate comparisons with known prophets from ancient times. Thus, this treatise includes evidence obtained from several classic texts, plus excerpts of Plato's writings, life experiences, influence from Socrates, and Plato's foreign travels. Also considered are biblical passages about prophets from the Old Testament. Thereby, a philosophical and theosophical investigation is undertaken to examine the extent to which Plato satisfies the criteria for being considered to have been a prophet in the classical sense.
\end{abstract}

Keywords: Plato, philosophy, prophet, Socrates, Old Testament.

\section{Introduction ${ }^{1}$}

Piecing together the clues from Plato's life and dialogues, plus writings of authorities on his philosophy in order to reveal his prophetic nature was, admittedly, a challenging task. For, although a good deal has been written about Plato's theology, there are only hints, suspicions, and unanswered questions that allow speculation on Plato's prophetic background. Of the scarce writings on this topic, there are a few examples to note. Belfiore (2006) asked if Plato was a prophet and briefly stated that his writings "adumbrated" (vaguely foreshadowed) western thought about art and literature, but did not examine Plato's personal life experiences as possible evidence of his prophetic nature, nor did it offer any detailed comparisons with biblical prophets. Jaeger (1927) offered only one brief sentence saying that Aristotle (who had once been Plato's student in the Academy) likely viewed Plato as a prophet. Pollard (1898: 328) stated that "Plato calls poets the "prophets of the Muses" and "in several respects are poet and prophet one" without mentioning Plato again; but if Plato's idea that poets are prophets is considered with the realization that Plato himself was a poet (see Hartland-Swann, 1951), then there is at least this basis for considering the possibility that Plato was a prophet (albeit, of course, that not all prophets are poets, and vice versa). Buber (1938/1997) came closest by comparing Plato with the biblical

${ }^{1}$ In this article, consistency has been maintained in the selected style of English spelling, except in quotations from sources that used a different spelling style. Language that is considered sexist has been avoided, except in quotations, which were not changed in order to maintain the verbatim integrity of the original sources. The word "God" appears often in Plato's writings, sometimes as a singular and sometimes as a plural noun, as well as being sometimes capitalized and sometimes not; thus, the source versions were used to preserve the original text.

(C) Authors. Terms and conditions of Creative Commons Attribution 4.0 International (CC BY 4.0) apply. Correspondence: Robert J. Taormina, Faculty of Social Sciences, University of Macau, Macau (SAR), CHINA. E-mail: Taormina@emeritus.um.edu.mo. 
prophet Isaiah, noting a few likenesses that might imply a type of similarity between the two personages. But it must also be noted that some authors opposed Buber's idea as being erroneous (e.g., Kroeker, 1993). This paper, then, is an attempt to piece together the fragments of the jigsawpuzzle picture of Plato's life and writings in an effort to bring into focus - as a coherent whole the hypothesis that Plato may be considered to have been a prophet.

For a discussion to be logical, it is necessary to begin by defining the nature, or essence, of the thing that is to be discussed. In this case it is a prophet, because, once the concept of a prophet has been defined, the definition can be consulted as the need arises. In this way, after reviewing the facts about, qualities of, or experiences in the life of a given individual, it becomes possible to determine whether a person - here, it is Plato - fulfills the criteria for being a prophet. Lindblom (1963), in his book on prophecy in ancient Israel, spent no little time analyzing just what these criteria would be. After touching on certain qualities of known prophets, such as the fact that they have been persons who have had something to "proclaim", which is typically in the form of a prediction or oracle (see Westermann, 1991), Lindblom (1963) was quite exclusive in his definition by deciding that a prophet is "a person who, because he is conscious of having been especially chosen and called, feels forced to perform actions and proclaim ideas which, in a mental state of intense inspiration or real ecstasy, have been indicated to him in the form of divine revelations" (p. 46). This, then, shall be the working definition in this treatise (while adding additional criteria as needed).

\section{Plato's early life}

When Plato's life is studied in an historical light, a better understanding is obtained not only of his writing, but of Plato himself. Also, to the extent that a person, in this case, Plato, the man, is a function of his environment, it becomes possible to determine what influences were at work on him.

Indeed, even in Plato's youth, there were so many social and cultural activities taking place in his aristocratic surroundings that it would have been impossible for him to not have been influenced in some way by the polytheistic rites, ceremonies, feasts, and orgies that were occurring in Greece at that time. Whereas Plato was born to a wealthy family in 427 BC (Hall, 2004), it is logical to surmise that he was quite likely to have been exposed to that sort of life, especially as his aristocratic family could well afford to partake of those culturally embedded activities.

Also, in concordance with wealthy families' participation in those cultural traditions, it was also traditional for a young man to undertake military training. Thus, Plato joined the military, and he excelled as a soldier, and had won prizes at the Isthmian Games (see Miller, 2004). Although soldiers today are not generally expected to be philosophically inclined, it was at that time that Plato encountered Socrates. Furthermore, Plato's love of competition (vis-à-vis military training and the Isthmian Games) could very well be what led him to enjoy the dialectic game of Socrates. According to Durant (1964: 12), Plato took such delight in this "sport" that he, in fact, became a devoted pupil of Socrates.

\section{Plato and the prophetic influence}

The intention of the following discussions (in the next two Sections of this treatise) is to show how the prophetic influence in Greece reached Plato, through both religious culture and through Socrates (see the next Section). Perhaps Dodds (1957) was the best authority to have discussed this question. Dodds argued that the early shamanistic (i.e., primitive or prophetic) culture still existed in Siberia (at the time of Dodds' writing) and left traces over a wide area "extending in a huge arc from Scandinavia across the Eurasian land-mass as far as Indonesia" (p. 
140); which, of course, includes Greece and even Judea. Thus, if Dodds' argument is correct, i.e., that prophecy in both Greece and Judea is derived from - and therefore shares - the same prophetic ancestry, one can begin to draw parallels between prophecy in Israel and in Greece. First, in Israel, there were known to have been prophetic groups (or guilds), e.g., "a company of prophets" (I Samuel 10:5-13 King James Version), and (as explained below) Socrates numbered among them as they existed in Greece.

Before proceeding, it should be remembered that other authors (e.g., Ghaffari, 2011) had also argued that Socrates was a real prophet. This suggests even more strongly that Plato could have been a prophet because he studied under and loved and respected Socrates in such a way that his joining the Socratic school may be compared to joining a prophetic guild.

\section{Evidence from Socrates}

To begin this inquiry, one should consult some of Socrates' speeches (albeit written by Plato). "Our greatest blessings", says Socrates in the Phaedrus (244a), "come to us by way of madness", which may be understood as a reference to divine madness or ecstasy (Dodds, 1957: 64). That gives direct evidence of shamanistic influence on Socrates, i.e., it is said in the Phaedo (6oe) that "he [Socrates] took dreams and oracles very seriously". And he habitually heard and obeyed an inner voice which knew more than he did (see Dodds, 1957: 185). Also, Plato indicated that Socrates had his own private oracle (Apology, 40a).

And there is further evidence in Plato's writings that Socrates had strong ties with Greek shamanistic, i.e., Corybantic, rites (Euthydemus, 277d). Those Corybantic rites were composed of three parts, each of which had a corresponding counterpart in Israeli tradition. The first was a musical ceremony that was often a purging of evil spirits, an Israeli counterpart of which (although more subtle) might be David's lyre playing to soothe Saul's spirit (I Samuel 16:14-23). The second Corybantic rite was a sacrifice by each participant to the god to whose music the participant had responded. And the third Corybantic rite was a dance that was performed by the individuals whose sacrifices were accepted. Comparable biblical references to the last two rites may be found in the form of sacrifices and dances, e.g., such as performed by David for Yahweh (II Samuel 6:16-18).

Before proceeding, it should be remembered that all the evidence for the prophetic nature of Socrates is intended to emphasize the same nature in Plato, who so greatly admired Socrates. Thus, it would probably be best to focus on the direct influence that Socrates had on Plato. Dodds (1957) gave additional testimony supporting this idea by stating that "Plato was no doubt influenced by Socrates' shamanistic practice of prolonged mental withdrawal" (p. 225); as described in the Symposium (174d-175c \& 220cd).

Dodds (1957), however, is not the sole advocate of this idea because Caird (1923) also discussed Socratic influences on Plato, and did so at length. Caird began by equating the Platonic Ideal with spirituality, e.g., Plato "is bent on establishing an ideal or spiritual conception of the principle of unity... an idea which he had derived from his master, Socrates" (p. 61), and "The idealistic or spiritualistic element in the Platonic thought is derived mainly, if not entirely, from Socrates" (p. 64). Also, in direct accord with Dodds' view, Caird also stated that "Socrates himself ... did not profess in all cases to guide his own life by ethical science, but fell back on what he called a divine voice that spoke within him, i.e., upon an unreasoned intuitive perception of what ought to be done, which he regarded as a kind of oracle of the gods" (pp. 72-73). This brings to mind a part of Lindblom's (1963) definition of a prophet, "He must say what has been given him to say and go where he is commanded to go" (p. 1). Moreover, in further discussion of Socrates, Caird (1923: 75) stated the following: 
His attitude was like that of a modern religious teacher who is endeavoring to make men feel the necessity of acting from the highest principle.... For what he seeks is not merely to make men act rightly, but to make them act upon the right motive; and he may even be inclined to accept the dangerous maxim that "whatever is not of faith is sin", and to treat the outwardly good and the outwardly bad as upon the same level, insofar as the former no less than the latter, want that deep religious principle from which alone, in his view, true moral life can spring.

This "acting from the highest principle" is another quality that seems to be common to all representatives of the prophetic type. Without much stretch of the imagination, one can draw an analogy between Socrates, who quashed dogmas and dispelled presumptions of the social elite of Athens, and Elijah, the Tishbite, who confronted the dogmatic prophets of Baal on Mount Carmel (I Kings 18:17-40). To further this analogy, Elijah chose Elisha to succeed him, and Elisha so revered Elijah that he asked for "a double share" of his spirit (II Kings 2:9) and completed the tasks assigned to Elijah. Similarly, there is abundant evidence of Plato's respect for Socrates, especially in the fact that Plato accredited Socrates for the arguments in all of his Dialogues. (Further meaning in this fact is discussed below.)

Thus, Plato, in his own way, carried on the work "assigned" to Socrates by continuing to utilize the Socratic Method. And, just as Elisha saw Elijah taken away in a chariot of fire (II Kings 2:11-12), so Plato had envisioned Socrates in a heavenly chariot that awaited him (Levy, 1956: 148). As for fulfilling Socrates' duty, Caird (1923) said of Platonic philosophy that it "may be described as an extension to the universe of the principle which Socrates applied to the life of the individual man" (p. 80). But this is not the final word, for there is yet more evidence of Socrates' religious experiences as discussed by Levy (p. 35) and Dodds (1957: 210), as well as Plato's admission that meeting Socrates was the most significant event of his life (Levy: 18, 35).

Returning now to the question concerning the presence of Socrates in the Dialogues as evidence of his influence on Plato, Ryle (1966), in Plato's Progress, took a much stronger stand than has been thus far maintained in this essay. Ryle argued that Plato "meant his public to identify his 'Socrates' with himself" (p. 169). Ryle also believed that "the bulk of Socrates' defence is no more historical than Thucydides' speeches are historical. The Apology is, for the most part, a defence of the Socratic Method" (p. 152).

Ryle (1966) further argued that writings such as the Apology, Crito, Meno, et al., were really dialogues that Plato wrote in defense of himself. Thus, Socrates was presented mainly as a figure, or character, in the allegorical dialectics. That view, says Ryle, introduces a very different man, i.e., "Socrates is now a prophet, a reformer, a saint and a martyr" as seen by Plato (p. 159). Thus, Plato's own recognition of Socrates as a prophet supports the analogy of the biblical "sons of the prophets" (I Samuel 10: 5-13).

\section{Evidence from Plato's travels}

With the execution of Socrates in 399 BC for his politico-philosophical views, Plato, as his follower, was wisely advised to leave Athens until the political ruffles that Socrates had caused were finally smoothed out in the minds of the Athenian citizens. Thus, Plato set out on long periods of foreign travel, which were broken occasionally by required service in military campaigns (Riginos, 1976: 51). Durant (1964) appears to have been very interested in Plato's travels, particularly to Egypt, by observing that Plato "was somewhat shocked to hear from the priestly class which ruled the land, that Greece was an infant state" (p. 13). There is also further evidence that Plato did indeed study for a time in Egypt, which brought him the knowledge of that nation's priests who taught him "the divine basis of her [Egypt's] society, and its relations to the heavenly circuits" (Levy, 1956: 26). Some authors have suggested that Plato might also have gone to Judea and that he was "moulded for a while by the traditions of the almost socialistic prophets; and even 
that he found his way to the banks of the Ganges, and learned the mystic meditation of the Hindus" (Durant, 1964: 13); but evidence to support that latter speculation has not been sufficiently documented.

It is known, however, that Plato sailed to Italy and Sicily and, for a time, joined the school (or sect) that Pythagoras had founded. And Pythagoras is universally regarded as a "seer" (Durant, 1964: 6). Thus, it now becomes evident that Plato was influenced by yet another mystictype person, namely, Pythagoras. Pythagoras, too, seems to have been inspired not only by the Greek shamans (Dodds, 1957: 143), but also by Egyptian practices, some of which he seems to have adopted (Ibid.: 171-172). There is also evidence of Greek syncretism (i.e., a combination or merging) with Egyptian religion that dates as far back as Socrates, for it was the Sun (Ra) to which Socrates offered a prayer in the mornings before he went about his daily activities (Symposium, 220d).

To return to Plato's travels, his first visit to Sicily, in the spring of $387 \mathrm{BC}$, took him to Tarentum (present-day Taranto) in Southern Italy, to visit his friend Archytas. Archytas was a distinguished statesman and mathematician, the city's chief administrator, and also a member of the Pythagorean Order, which was a religious and scientific community. As for the Pythagorean religion, Dodds (1957: 79, 154) noted that "some form of musical catharsis [much like that in David's time (I Samuel 16: 14-23)] had been practiced by Pythagoreans in the fourth century, and perhaps earlier". Dodds argued that it is known "that Pythagoras founded a religious order, a community of men and women whose rule of life was determined by the expectation of lives to come" (p. 144), and that they "are said to have avoided meat, practiced catharsis, and viewed the body as a prison. There cannot in fact have been any clear-cut distinction between the Orphic teaching, at any rate in some of its forms, and Pythagoreanism" (Dodds, 1957: 149). In the following discussion, evidence is offered to support the idea that many of these beliefs are expounded in Plato's later dialogues.

While in Tarentum, Plato talked each day with the Pythagorean leaders; and he also met with the "listeners", who studied the religious teachings of Pythagoras, which were conveyed by word of mouth (Phaedrus, 275bc). Through the Pythagoreans, Plato found the scientific and religious teachings to have been part of a single vision of the world, and Pythagoras taught him further that the advance of truth is also the revelation of beauty. So it was this Pythagorean view, i.e., that the body is the prison of the soul, that Plato especially noticed and took to mind. It was here, then, that Plato's purpose first emerged (see below for further explanation of the idea that the soul is imprisoned in the physical body).

Before turning to an analysis of Plato's writings, there is yet one more very critical aspect of his first visit to Sicily that must be investigated. It seems that Plato had hoped to visit the craters of Mount Etna before returning to Athens. Knowing this, Dion, a statesman from another Greek colony, invited Plato to visit Syracuse while he was on the island. Thus, Plato left for Sicily and camped on Mount Etna; and one historian viewed the three days that Plato spent there as having been tremendously meaningful for Plato (Levy, 1956: 34):

The second night found him deep in meditation. The cruelty of nature wounded him less than the violence of men, and this solitude, coming after the adventures of the previous months, had enormously enhanced his perceptions. A gigantic realization of unity suddenly enveloped him. The certainty of the oneness of all life... would seize his groping consciousness from time to time and always left a lasting mark behind it.

Furthermore, Ryle (1966), suggested that there was some significant occurrence in Plato's life at this time by stating "there must have been some crisis in Plato's life in the later $370 \mathrm{~s}$ which is reflected at once by the disappearance of the elenchus from his dialogues..., by the passion with which Plato writes in the Gorgias monologue and in the Apology, Crito, and Phaedo; and even perhaps by Socrates' very uncharacteristic lament at the divine veto on suicide in the opening 
conversation of the Phaedo" (Ibid.: 160).

With these two clues, could one suspect that a mystic experience had occurred for Plato at the volcanic craters on the peak of Mount Etna? This question may be asked because other prophets (especially Moses) are reported in the Bible to have received revelations on such "high places" where God appeared amidst smoke and fire (e.g., Exodus 19:18). Was it here in the form of a divine inspiration that Plato learned "the Idea of the Good" at first hand, just as other prophets of the Old Testament had received their calls?

This might not be an implausible idea because there are certain things about Plato that should be remembered. First, there is Plato's personality, namely, he was essentially a philosopher and thus could be expected to deal with the world, even the "divine world", in this way, i.e., as a philosopher. Second, as pointed out by Wright and Fuller (1960: 59-60) in speaking of the reason for God to choose a prophet, "there is no concern for religious experience - rather, just a concern for His purpose". Now consider what Lindblom (1963) explained, that is, "What can at all events be maintained is that the prophets receive their revelations in a state of inspiration which has a tendency to pass into ecstasy" (p. 35).

This event of Plato having climbed up to the volcanic craters at the top of Mount Etna and spending time there in deep contemplation seems to have been of such major importance, as evidenced by the changes which Plato and his writings underwent, that one might surmise just what form this experience could have taken. And it is not unreasonable to do this, for even Habakkuk awaited a vision that he was told to report (Habakkuk 2: 1-3). Therefore, in consideration of the fact that Plato, by virtue of his thought, writings, ideas, etc., was arguably the most influential figure in the history of the western world (exceeded, perhaps, only by Jesus Christ), it might well be conjectured that Plato had a perception of himself as having been given the task (by divine providence) of shaping the western world.

In whatever form this perception of Plato's might have been, it should be remembered that "a revelation may be a vision in the proper sense or an audition; but it may also be an inspiration of purely intellectual ideas, an inspiration with a content of abstract thought" (Lindblom, 1963: 23). If this is not enough evidence for accepting that Plato received visions, more evidence can be found in his writings, which virtually abound with them, e.g., the Phaedo 111b, Republic II 382e, VII 518, VII 532ac, VII 533c, X (Vision of Er), and Sophist 266c. Furthermore, there is another vision, i.e., one that Plato disguised as a myth in the Statesman, which must not go unnoticed. Specifically, according to Levy (1956: 137), Plato described it as a vision of God himself turning the wheel of the universe, and who, at the end of the cycle, lets it go.

At this point, one might ask whether Plato was a "seer" rather than a "prophet", but, as Lindblom (1963: 93) explained, "It is not easy to draw a definite dividing line between the 'seer' and the 'prophet' either in the pagan world or in ancient Israel" because both could, on occasion, execute the same functions. Therefore, whereas the same definition could serve for both a seer and a prophet, namely, an individual who claims to possess the faculty of knowing things that are concealed from ordinary people, these two terms may be considered to be interchangeable.

Hence, this event on Mount Etna, which Ryle (1966) called a "crisis", could, at the time of its occurrence, have led to confusion for Plato with regard to reconciling his earlier scientific writings with this new, divine knowledge. It seems, though, that the rest of his journey to Syracuse helped Plato immensely in solving this dualistic-like problem, for, contrary to the orthodox notion that Plato left Sicily disheartened by his failure to found his Ideal State, "the truth is that he left Sicily in excited possession of a new natural science" (Ibid.: 64).

Thus inspired, Plato returned to Athens and, taking the Pythagorean societies as his

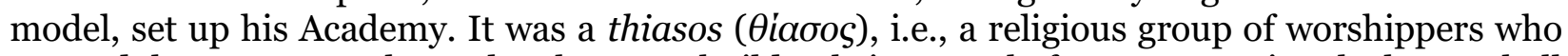
revered the Muses, to whom Plato began to build a shrine even before constructing the lecture hall 
or the library. Also, once a month, teachers and scholars would partake of a communal meal, at which Plato would always be present, in honor of the Muses. Here, then, is further evidence of Plato's mystic experience, i.e., because the Muses, to the Greeks, were the source of genius and inspiration. To clarify this point, an analogy may be drawn between the Muses and the Angels of the Lord because on various occasions in the Old Testament Angels of the Lord appeared to certain individuals to deliver revelations from God, thus defining those individuals as prophets (e.g., Joshua 5:13-15; Genesis 16:7, \& 19:1-23).

Other authors have pointed out Plato's familiarity with "divine madness", not only by showing that Plato was concerned with defining such "madness" as "possession by the Muses" (Dodds 1957: 71, 80), but also by Plato's frequent references to inspired prophets as a familiar contemporary type (Apology, 22c, Meno, 99c, Ion, 534c); and by Plato's intimate knowledge of Corybantic ritual (Ibid.: 75; see also Phaedrus, 244de). Nor does Plato hide the fact that he was accustomed to various types of inspiration, for, in the Symposium, he speaks of four types of divine madness, namely, prophecy, healing, poetry, and love.

With the foundation of the Academy, the intellectual life for Plato, as for Pythagoras before him, was to be an offering to God. This "intellect", which can be equated to "mind", or "soul", "is actually the mysterious vitality that makes one alive and gives him vigor according to biblical thought" (Wright \& Fuller, 1960: 101). From this point on, Plato's message and mission can now be understood. In short, he used philosophy as a discipline, or mantra, in the sense familiar to the Pythagorean Order, as a way to salvation. In line with this is "his deliberate... practice of mental withdrawal which purifies the rational soul - a practice for which Plato in fact claims the authority of a traditional lǒgos" (Dodds, 1957: 210). This purity, for Plato, had become a cardinal means to salvation.

Plato's message, according to classical literature, is basically that (from Plato's point of view) "the body is a kind of tomb of the soul from which it can rise only at death," and that life "has to be conceived as a practice for that final moment in which it shall free itself from this "muddy vesture of decay that doth so grossly close it in' (Phaedo 79c) and hinder it from the vision of the intelligible world" (Caird, 1923: 115-116). Thus, it seems that Plato's purpose was a social attempt (like that of the biblical Amos, whose concern was with social injustice) to build a bridge between the intellectuals and the people, and thereby save the unity of Greek belief and of Greek culture.

One might ask how Plato proposed to achieve his mission to save Greek beliefs and culture. The answer is "by teaching," so that the soul (or mind, or intellect, as the three were equated by Plato) will be purified by a clearer understanding of nature, raising itself by steppingstones of logic until it has attained an understanding of the One beyond the Many, the One Wisdom that comprehends the One Beauty. Just how this could be accomplished was explained by Levy (1956: 69):

At first, he [the student] will learn from his own intense experience that the beauty of one person has kinship with that of another. So, he becomes a lover of all corporeal beauty, and his compassionate love of one will seem in comparison a small thing. Then fair souls will have more value to him than fair bodies, and in company with such souls he will bring to birth the beauty of moral law and of abstract thought. So being no longer a bondsman to single beauty, he arrives at last at the great ocean of beauty.... When a man has ascended from those beauties by the right way of love, using them as steps of a ladder, and begins to perceive that Beauty, he has reached his goal.

Thus, Plato provided a picture of a process of education, or elevation of the soul (Symposium 210a), which begins in the wonder and desire produced by the outward beauty of one finite individual and that rises by gradual steps from the body to the soul, from one to all beautiful forms, until it finds at last its perfect satisfaction in the contemplation of the ideal principle of 
beauty itself. Plato, then, was striving for unity, seeking to merge the particular in the universal and the temporal in the eternal, and, ultimately, to lose the intelligible world and the intelligence in an absolute divine unity. That is, he sought to liberate the corporeal person from the prejudices of the natural understanding, and to open up (for any person) an ideal world in which one can find refuge from the narrowness and inadequacy of life.

To better understand what Plato was trying to do, perhaps it would be beneficial to consider his idea of the natural progression of the souls. The Timaeus, which, theologically speaking, is considered one of Plato's latter compositions might be thought of as his final doctrine, i.e., something in the nature of Plato's Book of Genesis, because it is very much his address on the origin of the World and of Mankind. Therein, one learns that souls are formed by an entity that is subservient to the gods, namely, the Demiurge (Timaeus, 41d-42d); subsequently, the souls are sown in the Earth and then the gods establish mortal parts of the body to frame the soul. Thus, the soul, at its first coming into the body is crushed and overwhelmed by its mortal nature and loses all memory of the higher life in which it had previously partaken. Thus shocked, the soul becomes impure, and Plato's thought was to purify it because he was convinced that the nature of God is good and did not mean for the soul to become impure, but rather to gain intelligence. This is revealed in Plato's description of God (Timaeus, 29e et seq.):

In a perfectly good being, no envy or jealousy could ever exist in any case or at any time. Being thus far removed from any such feeling, he desired that all things should be as like himself as it was possible for them to be.... God desired that everything should be good and nothing evil, so far as this was attainable. Wherefore, finding the visible world not in a state of rest but moving in an irregular and disorderly fashion, out of disorder he brought order, thinking that in every way this was better than the other. Now it is impossible that the best of beings should ever produce any but the most beautiful of works. The Creator, therefore, took thought and determined that out of the things that are by nature visible, no work, destitute of reason, could be made which would be so fair as one that possessed reason.... He also saw that reason could not dwell in anything that is devoid of soul. And because this was his thought, he put intelligence in soul, and soul in body, that he might be the maker of the fairest and best of works.

Thus, Plato had turned his idealism into spiritualism by treating soul, or intelligence, as the only thing that can be regarded as active, or self-determined. He suggested that all souls are to be viewed as derived from, or dependent on, one divine soul or spirit that manifests itself in and to them. Hence, the idea is to purify the soul by teaching and learning justice, temperance, reasoning, wisdom, etc., so that all individual minds are reflected back to one supreme intelligence who is the "first mover" of all things, and who communicates life and intelligence to all other minds or souls. As Caird (1923: 201) explained, the soul is...

[a] memory of a former state of existence, a memory which has become dulled or obscured by the descent of the spirit into the world of sense. This memory may be revived by reflection and dialectic, though it cannot become completely restored till death liberates the soul from the body and its affections. The soul therefore is to be conceived as remaining unchanged in its essential nature through all the processes of birth and death; as being many times born into the sensible world and departing from it again, but ever maintaining the continuity of its life, and carrying with it, in a more or less explicit form, all the knowledge it ever possessed.

\section{Plato compared to biblical prophets}

It now becomes feasible to make some more direct comparisons between Plato and other prophets, such as Amos and Hosea. The first comparison relates to the universality of Plato's theology, for his God is the One beyond the Many (see the Timaeus in its entirety), just as the God 
that Amos knew is a universal God (Amos 1 \& 2). Also, just as Amos hoped to "help Jacob stand" (Amos 7:2-3), Plato hoped to aid humankind in the aspiration of their souls; such as in the Phaedo, where Plato's argument is that the soul must be lifted above time and change. And, in accordance with Amos' command to "Hate evil and love good" (Amos 5:15), a theme expounded by various other prophets as well (Isaiah 13:11; Jeremiah 13:23; et al.), Plato had developed an entire theory on evil (e.g., Timaeus, 86d-87b), so much so that he was almost obsessed with the Idea of the Good. This Idea seems to be the premise upon which he based much of his life, hopes, and theology. It also appears, probably most emphatically, in his Republic, i.e., his Ideal State. In Book I, the Idea of the Good is presented as the goal of an individual's life, which each person must discover for one's own self.

Then, in Book II, the next stage, everyone is shown to be essentially social so that everyone can find one's own good in that place in society where one's special capacities fit. Yet, to Plato, it is the philosopher who attains the highest good, and after being exposed to the Idea of the Good, the philosopher is compelled to return to the sensible world. Thus comes the obvious, if implicit, indication of Plato as a prophet when he (in Socrates' words) gives an analogy in the seventh book of the Republic, i.e., of the world of "Becoming" as a "Cave" in which humans are bound, and the world of "Being" as a world upon which the "most brilliant light of Being" shines (Republic, VII, 514):

And now... let me show in a figure how far our nature is enlightened or unenlightened: Behold! Human beings living in an underground den, which has a mouth opened towards the light and reaching all along the den; here they have been from their childhood, and have their legs and necks chained so that they cannot move, and can only see before them, being prevented by the chains from turning round their heads. Above and behind them a fire is blazing at a distance, and between the fire and the prisoners there is a raised way; and you will see if you look, a low wall built along the way like the screen which marionette players have in front of them, over which they show the puppets.

The allegory of the cave proceeds to explain that the prisoners would mistake the shadows for realities. And when released, they would persist in maintaining that the shadows are the superior truth.

And if one is compelled to look straight at the light, will he not have a pain in his eyes which will make him turn away to take refuge in the objects of vision which he can see, and which he will conceive to be in reality clearer than the things which are now being shown to him? ...

Last of all he will be able to see the sun, and not mere reflections of it in the water, but he will see it in its own proper place, and not in another; and he will contemplate it as it is....

And when he remembered his old habitation, and the wisdom of the den and his fellow prisoners, do you not suppose that he would felicitate himself on the change, and pity them?

But when that person returns to the den, Socrates explains, that person would see much worse than those who had never left the den, as Socrates further explains (Republic, VII, 517):

Men would say of him that up he went and down he came without his eyes; and that it was better to not even think of ascending; and if anyone tried to loose another and lead him up to the light, let them only catch the offender and they would put him to death....

This entire allegory... you may now append, dear Glaucon, to the previous argument; the prison-house is the world of sight, the light of the fire is the sun, and you will not 
misapprehend me if you interpret the journey upwards to be the ascent of the soul into the intellectual world according to my poor belief, which, at your desire, I have expressed - whether rightly or wrongly God knows. But, whether true or false, my opinion is that in the world of knowledge the Idea of Good appears last of all, and is seen only with an effort; and, when seen, is also inferred to be the universal author of all things beautiful and right, parent of light and of the lord of light in this invisible world, and the immediate source of reason and truth in the intellectual; and that this is the power upon which he who would act rationally either in public or private life must have his eyes fixed.

One may recall that "the special gift of a prophet is his ability to experience the divine in an original way and to receive revelation from the divine world" (Lindblom, 1963: 1) and "common to all representatives of the prophetic type... is the consciousness of having access to information from the world above and experiences originating in the divine world, from which ordinary men are excluded" (p. 32). When looking at Plato's writings in this light, one no longer wonders whether Plato had "special access" in order to discover the analogy described above, i.e., in the "vision" (allegory) of the "Cave". Rather, one realizes that Plato was revealing that he had special knowledge not known to everyone!

Hence, knowing also that Plato's absolute confidence is in philosophy as the supreme gift of God to humankind, one can understand thought and reason to be the highest and most perfect activity of the spirit, which brings one nearest to the divine. Plato believed it is only because this activity is obstructed and weakened by mortal nature that people do not know God fully as God really is. Similarly, according to Caird (1923: 150), Plato thought...

that faith in God - a faith that good is stronger than evil and is all-powerful - is the necessary basis of our higher life, and that without some such faith, morality is apt to shrink into a hopeless striving after an unattainable ideal and must cease to exercise its highest inspiring power. To hold what we regard as best and highest is also the ultimate reality - the principle from which all comes and on which all depends - is the great religious spring of moral energy.

Hence, Plato was the philosopher-prophet who lived his life in contemplation of the universe and apprehended the principle of order that is manifested in it. And it was he alone (according to Plato) who could give the State its ideal constitution. Only Plato could make all things "after the patterns shown to him on the Mount". That would be Mount Etna, which is a remarkable parallel to what happened to Moses on Mount Sinai, i.e., God offered Moses a covenant for the people of Israel so they could ascend to heaven if they obey the "pattern" of the Ten Commandments. In other words, Plato, during his stay on Mount Etna, might have been inspired with the realization regarding how the soul could ascend to its highest level, namely, by understanding the "pattern" depicted in the Allegory of the Cave. This deduction is conceivable because the parable of the cave was written after Plato's first visit to Sicily in 387 BC, whereas the Republic, in which the cave allegory appeared, was written in 374 BC (Brickhouse \& Smith, 2018), before his second visit in 366 BC (Guthrie, 1975: 437). And according to Levy (1956: 78-91), that is precisely what Plato tried to accomplish during his second visit to Sicily, where he was requested to act as the tutor for Syracuse's dictator, Dionysius the Younger (who, unfortunately, proved to be a very incompetent student).

To continue with the present comparison, this view of the Republic can be seen somewhat as an attempted Exodus in which a Moses-like Plato tried to lead his chosen people out of domination from an immoral and corrupt land. In this same sense, Plato can be compared to Hosea. Where Hosea called to the people to return to the desert (Hosea 2:14-15), which was really a call for an earlier and more direct relationship with God, Plato, too, as seen in the passages from the Republic (quoted above), was attempting to lead people to enlightenment. But he knew that such an attempt would be opposed even by those he was attempting to help. And the Gorgias can 
even be used as a source of direct evidence that Plato himself did deliver orations on social and political matters, and that they brought him great unpopularity. This is precisely what had also happened to Amos (Amos 7:12-13).

Finally, in Plato's Laws, social codes are expounded that are comparable to those in Leviticus. For example, Laws IX, 878a, speaks of ritual sacrifice for atonement; and a similar theme can be found in Leviticus 16. Also from Leviticus 19:2, comes the idea of filial obligation, for which Plato's strongest comparable writings can be found in Laws IX, 881a, where death is considered not too severe a penalty for persons who had committed violence (specifically murder) perpetrated against their own family members.

\section{Conclusion}

This article revealed the development of Plato's prophetic concern for the soul in his writings, beginning with the early Phaedo, where he adopted the simple Socratic opinion that moral error is a kind of mistake in perspective, i.e., that no one commits an error if that can be avoided; to the Republic (IV, 441b), with theory transmuted and elevated to where "passions of the body" become an internal dialogue between parts of the soul; and then on to the Timaeus (69c), in which Plato tried to reformulate his earlier vision in terms compatible with his later psychology and cosmology (Cornford, 1937). Briefly, Plato revealed that only after one has mastered the nature of the parts taken in isolation would it be safe to go on to recognize that, after all, they are not isolated. Here is revealed his prophecy that science can go only so far and then must admit to spirit, for, to paraphrase Plato in the Timaeus, it is just when analysis had done its work as completely as possible that a person becomes clearly conscious that no final account of being can be given until the person has discovered the one principle that manifests itself in all its differences and binds them into one organic whole.

And only after his attempt at trying to make his Republic become a reality (in Sicily), did Plato return with his keenly stringent Laws, where he proposed everything from saving Greek society (Laws, 85d), which may be compared to Isaiah, whose "remnant shall return" (Isaiah 1: 19), to denouncing false prophets (Laws, 909b), comparable to Micah 2:6; all of which is accompanied by severe punishment for miscreants, particularly in Laws, 907d-910e, which may be likened especially to Amos for this theme.

In conclusion, the evidence appears to provide testimony for seeing Plato as a prophet; from his poetic style of writing (compare the Hebrew Torah), through his various dialogues, which abound with documentation regarding his mystic experiences, and on to his visions and prophecies. Perhaps the best summary of the considerable evidence that has been accumulated for considering Plato to number among the prophets would be a brief synopsis of Plato's life, as provided by Caird (1923: 216):

In short, life for Plato is the life of intelligence more or less adequately realized.... Hence, the individual who is capable of moral and intellectual activity - who... can become a "spectator of all time and existence," and who, in his practical efforts, is guided by a consciousness, or at least a foretaste and prophetic anticipation, of the universal good.

\section{Acknowledgements}

This research did not receive any specific grant from funding agencies in the public commercial, or not-for-profit sectors.

The author declares no competing interests. 


\section{References}

Belfiore, E. (2006). The unacknowledged legacy: Plato, the Republic, and cultural policy. International Journal of Cultural Policy, 12(2), 229-244. https://doi.org/10.1080/10286630600813743

Brickhouse, T., \& Smith, N. (2018). Dating Plato's dialogues. The Internet Encyclopedia of Philosophy, https://www.iep.utm.edu/plato/ (retrieved 2 April 2019).

Buber, M. (1997). Plato and Isaiah. In: M. Buber (Ed.), Israel and the world: Essays in a time of crisis (pp. 103-112). Syracuse, NY: Syracuse University Press.

Caird, E. (1923). The evolution of theology in the Greek philosophers, Vol. 1. Glasgow: MacLehose, Jackson, \& Co.

Cornford, F. M. (1937). Plato's cosmology. New York: Harcourt, Brace \& Co.

Dodds, E. R. (1957). The Greeks and the irrational. Boston: Beacon Press.

Durant, W. (1964). The story of philosophy. New York: Washington Square Press.

Ghaffari, H. (2011). Is Socrates a prophet? Sophia, 5o(3), 391-411. https://doi.org/10.1007/s11841-0110266-0

Guthrie, W. K. C. (1975). A history of Greek philosophy, Vol. 4: Plato, the man and his dialogues: Earlier period. Cambridge: Cambridge University Press.

Hall, R. (2004). Plato. Abingdon, UK: Routledge.

Hartland-Swann, J. (1951). Plato as poet: A critical interpretation. Philosophy, 26(96), 3-18. https://doi.org/10.1017/So031819100019161

Jaeger, Werner (1927). Aristotle's verses in praise of Plato. The Classical Quarterly, 21(1), 13-17. https://doi.org/10.1017/So009838800000951

Kroeker, T. (1993). The theological politics of Plato and Isaiah: A debate rejoined. The Journal of Religion, 73(1), 16-30. https://doi.org/10.1086/489051

Levy, G. R. (1956). Plato in Sicily. London: Faber \& Faber.

Lindblom, J. (1963). Prophecy in ancient Israel. Philadelphia: Muhlenberg Press.

Miller, S. G. (2004). Arete: Greek sports from ancient sources. Oakland, CA: University of California Press.

Pollard, E. B. (1898). The prophet as a poet. The Biblical World, 12(5), 327-332. https://www.journals.uchicago.edu/doi/pdfplus/10.1086/472360

Riginos, A. S. (1976). Platonica. Leiden: E.J. Brill.

Ryle, G. (1966). Plato’s progress. Cambridge: Cambridge University Press.

Westermann, C. (1991). Basic forms of prophetic speech. Westminster: John Knox Press.

Wright, G. E., \& Fuller, R. H. (1960). The book of the Acts of God. NY: Doubleday. 